


\section{Section 7, Insite and the Competence of Courts}

\section{Jeremy Webber ${ }^{*}$}

In the Insite case, ${ }^{1}$ the plaintiffs came to court with a very specific end in mind: to preserve the Insite safe-injecting facility. They did so for reasons of substantive justice: they wanted to protect drug users from the dangers of injection in the back alleys of the Downtown Eastside and to mitigate the harms common to that drug use-virulent infections and the risk of death from overdose.

As in many constitutional cases, the courts' decisions deal with these issues only partially and often indirectly. They are largely focused not on the substantive justice of the plaintiffs' claim, but rather on jurisdiction-most obviously the jurisdiction of the federal Parliament in relation to the B.C. legislature and less obviously on the jurisdiction of the courts vis-à-vis the other branches of the state (the executive and legislature).

That kind of disjuncture between plaintiffs' objectives and court's decision is common. It can cause intense frustration to plaintiffs for it seems to miss the very point of the litigation. But issues of jurisdiction do deserve our attention. They are not just distractions or matters of political power. They too speak to real issues of justice, even if those issues are far removed from the compelling needs of the Downtown Eastside.

Jurisdictional questions are founded on the need to make societal decisions when society is not unanimous; indeed, even when members of society intensely disagree. Because of that disagreement those of us who participate in the legal system cannot simply impose what we take to be right. Why should we be entitled to make our personal opinions law? We need to be concerned not just with the substance of the matter (though we do need to be concerned with that), but also with the process by which decisions about that substance are made. Who should make the decision? Through what procedure? With what kind of public and evidentiary input? These questions are fundamentally institutional, often jurisdictional. And they form the very fabric of self-government in a democracy. If we care about our ability to govern ourselves, we have to care about issues of jurisdiction.

Those questions are the focus of this comment. I will not discuss the most obvious question of jurisdiction: the contest between federal authority over the criminal law and provincial authority over health. Instead, I will focus on a second and less obvious set of jurisdictional concerns - those that address the relationship between the courts and the executive and legislature, especially in the application of section 7 of the Canadian Charter of Rights and Freedoms. ${ }^{2}$

The application of section 7 of the Charter is never purely about the vindication of "life, liberty and security of the person" so that deprivations are kept consistent with "fundamental justice." That language is so general, its potential reach so vast and therefore so subject to reasonable dispute, that judges need to ask themselves a second set of questions, at least implicitly. They need to ask what potential definitions of life, liberty, security of the person, and fundamental justice lie within their competence, so that they are justified in second-guessing the other branches' decisions on these matters. 
Their answers cannot be purely personal. We do not appoint judges as philosopher kings to elevate their individual views into law because of their great wisdom or exceptional insight. Rather, they are appointed to make certain kinds of decisions because of the specific institutional characteristics of courts. Because their legitimacy as decision makers depends on the nature of courts, judges have to tailor their decision making to situations where their institutional strengths are present-where the characteristics of courts allow judges to make especially dependable decisions, or decisions that focus on concerns that might otherwise be overlooked. Judges have to ask themselves, "What kinds of decisions are appropriate for me and my colleagues to decide? What sense of fundamental justice, what forms of life, liberty and security of the person, do the nature of my office and the procedure by which matters are argued before me prepare me to decide? And what judgments of justice, what aspects of life, liberty and security of the person, lie outside my competence, so that those decisions are best left to a democratic and participatory process?"

Now, in the early years of the Charter (the years of the Dickson court), the Supreme Court of Canada did a good job of making these judgments. One had the impression that the judges asked themselves where their distinctive expertise lay and tried, to the extent possible, to tailor their decision making to that competence. That did not mean that the Court was timid. Its reputation from that time remains one of great activity and accomplishment. In decisions like Hunter v Southam, Oakes, Edwards Books, Morgentaler, Andrews, and Irwin Toy they mapped, with balance and care, the essential content of Charter rights. ${ }^{3}$ That accomplishment was founded on the Court's sure-footed assessment of what judges could reasonably determine.

The Court has stumbled since that time, with particular low points being the majority decisions in RJR-MacDonald (in which the Court struck down a ban on cigarette advertising) and Chaoulli (in which the Court invalidated restrictions on the purchase of private health insurance). ${ }^{4}$ In each of those cases, the majority of the Court lost sight of its particu- lar role and strayed into areas of complex policy making for which it had neither the expertise nor the evidentiary tools. It therefore imposed its will in ways that seemed arbitrary, out of keeping with the strengths of the judicial role and unsophisticated in its understanding of the policy process. The Court may be returning to a greater awareness of its capacities. The contributions of judges with extensive knowledge of government and administrative tribunalsBinnie, LeBel and Abella JJ in particular-have injected a much better sense of what is involved in complex processes of democratic decision making and, as a result, a better understanding of the added value that a court can bring. I do not mean that these judges form a bloc apart from the other members of the Court. The division of opinion and range of contributions on the Court are much more complex than that. My point is simply that these judges' institutional sense has been an important addition to the collegial decision making of the Court. ${ }^{5}$

Like many cases, Insite too raises questions of institutional competence and role: What kinds of issues are the courts well suited to decide? What should they leave to a more participatory and egalitarian process? And in that regard, the most relevant precedent for Insitethe majority of the Court's decision in Chaoulli-is unhelpful.

Now, the precedential force of Chaoulli should not be exaggerated. It was heard by only seven of the nine members of the Supreme Court of Canada. Only three members of the Court would have struck the impugned provision down on the basis of the Canadian Charter and this against the vigorous opposition of three other members of the Court. The actual decision rested on the Québec Charter of Human Rights and Freedoms, not the Canadian Charter, and, as I have argued elsewhere, substantially different considerations-considerations directly related to the issues of institutional competence discussed here-apply to statutory as opposed to constitutionally entrenched bills of rights. ${ }^{6}$

The interpretation of section 7 of the Canadian Charter is not, then, bound by Chaoulli. And there is good reason to decline to follow the reasoning of the three judges in that case 
who would have invalidated the provision on the basis of the Canadian Charter. Their reasoning was founded, in the end, on a policy judgment: on the supposed ability of the government to attain its objectives without having to rely on the provision that had been attacked-one that excluded the purchase of private health insurance for medical services that are available within the public system. The judges apparently reached that conclusion on the basis that other countries' health insurance schemes had been framed without relying on a "single payer" model, although the judges did so without assessing how well those systems worked, whether the alternative created two tiers of health care, or whether the existence of two tiers meant that most people were worse off. It might be argued that the Court had good reason to shy away from such complex judgments of comparative health policy but, if so, the three judges would have been well advised not to base their decision on just such a comparative judgment. ${ }^{7}$ One gets the clear sense that, for those three judges in Chaoulli, a complex policy judgment was trumped by the simple desire to allow individuals to deploy their own resources in seeking medical care, regardless of whether fostering private delivery would impair the public system so that the bulk of the Canadian population would be worse off. The three judges' decision has been justly criticized for overstepping the bounds of judicial competence by intruding deeply into realms of policy in which courts are not expert. ${ }^{8}$

Does the same conclusion follow in Insite, which again involves the application of section 7 to health services? Interestingly, I think the considerations are significantly different.

First, the issues are much simpler. As framed at trial and at appeal, the debate in Insite is not about the relative merits of different forms of intervention in preventing addiction or discouraging drug use, and it does not involve complex issues of program design and funding, such as those presented by a scheme of universal health insurance. In Insite, the essential finding on which the trial judge based his decision was consistent with the evidence submitted by all parties: "The risk of morbidity and mortality associated with addiction and injection is ameliorated by injection in the presence of qualified health professionals." 9 The federal government justified its refusal to extend Insite not on grounds of health policy, but as follows (as summarized by the trial judge):

\section{[T] he compelling state objective of prohibiting the use of hard drugs which are dangerous to users and to society at large, the linkage of the drug trade to organized crime, and the opposi- tion of the international community to narcot- ics as evidenced by treaties, mean that s. 4(1) is rationally connected to a reasonable appre- hension of harm, not arbitrary, and therefore not offensive to the principles of fundamental justice. ${ }^{10}$}

The essential question regarding section 7 was therefore much more straightforward than that posed in Chaoulli: Should the condemnation of drug use trump the known consequences to the lives and health of those using Insite? Moreover, this condemnation appeared to be based not on the capacity to stamp out the drug trade-no one presumed that this would occur-but simply on the desire to send an unequivocal message that illicit drug use was wrong.

Second, this conflict of considerations is precisely of the kind that judges are well placed to decide. The best justification for the independence of the judiciary is that the application of law should be insulated from the determination of general policy objectives, so that judges attend carefully to the particular facts of the case and do not distort their judgment in the interest of attaining a general policy goal. This ensures that issues pertaining to individuals are judged, to the extent possible, on the basis of a conscientious application of the law to the particular situation. A similar conception of the courts' institutional strengths-judges' capacity to attend to the detail of the law's application, without their view being distorted by close involvement in the policy process-also justifies their role in vindicating individual rights. ${ }^{11}$ They focus on the impact of governmental decisions on specific individuals, an individual impact that may be given short shrift in the executive's or legislature's rush to achieve a general policy objective. 
There is, then, an implicit division of labour inherent in the independence of the judiciary: legislatures are rightly focused on attaining general aims; courts focus on the individual case that might otherwise be overlooked. And that division is at the heart of Insite. The federal government is focused, above all, on affirming a general proposition: the unequivocal condemnation of drug use. And the courts are asked whether, in the rush to attain that objective, insufficient attention has been paid to the position of drug users, as individuals, in the Downtown Eastside.

Third, those drug users are among the most marginalized members of Canadian society: broken down, heavily addicted, often indigenous, and certainly not people who have ready access to the political process. Indeed, where their representatives have had real presence within democratic processes-in the City of Vancouver-there has developed, over time, very strong support across political lines for harm reduction measures, including the establishment of Insite. Thus, if one of the principal reasons for deference to executive and legislative decision making is the scope for strongly participatory engagement in the latter, Insite deals with a constituency that has routinely been excluded. Now, the courts should not judge the participatory nature of legislative processes too finely. There is a real danger that, if courts set the standard of participation too high, they might replace processes that allow at least some opportunity for citizens' direct participation with their own highly unparticipatory processes, all in the name of an unattainable perfection. But if there ever was a clear case of an excluded constituency, Insite is it.

Fourth, the Court's resolution of this dispute would not fall into the trap of treating rights as a simple matter of limiting government. Judges are often tempted to think that freedom is best achieved through the limitation of state power, so that individuals are left to do whatever they want. Private options, pursued by individuals using their own property, are taken to be the essence of liberty; government action, which constrains what individuals can do with their own property, is suspect. Arguably, that presumption shaped the majority's decision in Chaoulli, for the majority treated private health care as the default position, to which individuals should have access even if the growth of private health care ultimately makes most Canadians worse off. This, of course, is an impoverished conception of rights. It neglects the fact that individuals' options are often constrained by a lack of property, that domination occurs within the private as well as the public sphere, and that government action often results in the extension of rights, not their constriction. Even in the heartland of human rights (non-discrimination, freedom of expression, freedom of religion), the vast majority of rights claims are vindicated under human rights acts adopted by the legislatures. And of course, a right to health care or a right to education only exists because governments provide those services.

In the Insite case, the courts are addressing a carefully elaborated regime, developed through democratic action, with input from all constituencies, including the Vancouver Police and health authorities. The regime is carefully blended and seeks to co-ordinate four aims: prevention of drug use; treatment of addicts; enforcement of drug laws; and harm reduction. The result of a successful challenge would not be a free-for-all, but a careful strategy, designed through a highly participatory process, focused on both protecting the life and health of addicts and discouraging drug use.

Now, the Court should be careful not to set this regime in constitutional cement. The regime was developed as a medical trial. The effectiveness of Insite may, over time, be shown to be limited. Studies may reveal that harm reduction strategies have unforeseen effects that augment, not reduce, the incidence of drug use (although the evidence produced in Insite suggests the opposite). Moreover, the Insite decisions were the result of a summary trial on affidavit evidence. The federal government may decide that it can justify a prohibition on more complex policy grounds and provide evidence of those grounds, together with the policy process that led to its decision. If so, then the Court may once again confront the limits of its competence and have to defer to the more inclusive, participatory and 
investigatory processes of the executive and legislature. The Supreme Court should therefore confine its decision to the material before it and acknowledge that a different result might obtain if and when different information is presented to the Court. But, as framed, the issues in Insite fall within the Court's competence.

It is sometimes assumed that the relative role of courts and legislatures should depend upon how controversial a particular question is. On that view, courts should generally refrain from deciding matters of political controversy. But that is not my argument. Without a doubt, courts are called upon to make difficult and contentious decisions (as the Supreme Court has repeatedly recognized). ${ }^{12}$ Rather, judicial deference to the decisions of the executive and legislatures should depend upon the nature of the issue and the relationship between that issue and the institutional strengths and weaknesses of the three branches of government. For the reasons given here, the issues in the Insite litigation fall within the traditional strength of courts.

\section{Notes}

* Canada Research Chair in Law \& Society, Faculty of Law, University of Victoria; Director, Consortium on Democratic Constitutionalism (Demcon); 2009 Trudeau Fellow. My thanks to Gillian Calder and Andrew Petter for their comments on previous versions of this paper. All errors, of course, remain my own.

1 PHS Community Services Society v Attorney General of Canada, 2008 BCSC 661; PHS Community Services Society $v$ Canada (Attorney General), 2010 BCCA 15.

2 Canadian Charter of Rights and Freedoms, Part 1 of the Constitution Act, 1982, being Schedule B to the Canada Act 1982 (UK), 1982, c 11, s 7: "Everyone has the rights to life, liberty and security of the person and the right not to be deprived thereof except in accordance with the principles of fundamental justice."

3 Hunter $v$ Southam Inc, [1984] 2 SCR 145; $R v$ Oakes, [1986] 1 SCR 103; R v Edwards Books and Art Ltd, [1986] 2 SCR 713; $R$ v Morgentaler, [1988] 1 SCR 30; Andrews $v$ Law Society of British Columbia, [1989] 1 SCR 143; Irwin Toy Ltd v Quebec (Attorney General), [1989] 1 SCR 927.

4 RJR-MacDonald Inc v Canada (Attorney Gen- eral), [1995] 3 SCR at 199; Chaoulliv Quebec (Attorney General), [2005] 1 SCR at 791.

5 See, for example, Binnie and LeBel JJ's dissent in Chaoulli, ibid; the decision of Deschamps and Abella JJ in Multani $v$ Commission scolaire Marguerite-Bourgeoys, [2006] 1 SCR 256; and the Court's decisions in AC $v$ Manitoba (Director of Child and Family Services), [2009] 2 SCR 181 and Withler $v$ Canada (Attorney General), 2011 SCC 12.

6 Jeremy Webber, "A Modest (but Robust) Defence of Statutory Bills of Rights" in Tom Campbell, Jeffrey Goldsworthy \& Adrienne Stone eds, $\mathrm{Hu}$ man Rights Without a Bill of Rights: Institutional Performance and Reform in Australia (Aldershot: Ashgate, 2006) at 263.

7 Especially when intensive studies of these issues by both a Royal Commission and a Senate Committee had concluded in favour of maintaining a single-payer model of health insurance: Commission on the Future of Health Care in Canada, Building on Values: The Future of Health Care in Canada: Final Report (Ottawa: The Commission, 2002); Senate, Standing Senate Committee on Social Affairs, Science and Technology, The Health of Canadians-The Federal Role: Final Report (October 2002) (Chair: Michael JL Kirby).

8 For examples pro and con, see Colleen Flood, Kent Roach, and Lorne Sossin, eds, Access to Care, Access to Justice: The Legal Debate Over Private Health Insurance in Canada (Toronto: University of Toronto Press, 2005).

9 PHS Community Services Society (BCSC), supra note 1 at para 87. See also Brandon DL Marshall et al, "Reduction in Overdose Mortality after the Opening of North America's First Medically Supervised Safer Injecting Facility: a Retrospective Population-based Study," online: (2011) The Lancet DOI:10.1016/S0140-6736(10)62353-7 $<$ www.thelancet.com $>$.

$10 \quad$ Ibid at para 148.

11 Webber, supra note 6, at 275-81.

12 See, for example, Reference re Secession of Quebec, [1998] 2 SCR 217 at paras 24-31. 